\title{
INNOVÁCIÓ TERVEZÉSE BIZTONSÁGOS TERMÉKEKÉRT
}

\section{INNOVATION DESIGN FOR SAFE PRODUCTS}

\author{
Csongvai Roland, ${ }^{1}$ Torkos Zoltán ${ }^{2}$ \\ Erdélyi Múzeum-Egyesület, Kolozsvár, Románia \\ ${ }^{1}$ csongvai.roland@gmail.com \\ 2z.torkos@upcmail.hu
}

\begin{abstract}
Innovation \& product safety in the case of the EC \& Hungarian SMEs is a top priority, where product safety is also a legal obligation. Despite this, innovation design is dealt with inadequately by the majority of companies, and this is due to lack of knowledge or competency, especially considering the processes related to the design of safe products. Improper behaviour in the design stages results in losses for the companies - losses due to the inadequacy of otherwise innovative products. Inadequate or poorly applied directives/policies, especially when coded into processes influence not only the safety of the products but can result in delays to market access, significantly increasing costs \& development time, as well jeopardising the product's acceptance on the future market.
\end{abstract}

Keywords: innovation, product design, product safety, design, regulation.

\section{Összefoglalás}

Az innováció és termékbiztonság az EU és a Magyar KKV-k esetében kiemelt prioritás, a termékbiztonság pedig még jogszabályi kötelezettség is. Ennek ellenére a cégek nagy része tudáshiány, vagy a megfelelő kompetencia hiánya miatt nem megfelelően kezeli az innováció tervezését, különös tekintettel a biztonságos termékek fejlesztéséhez kapcsolódó folyamataikat, hatalmas károkat okozva ezzel saját maguknak, az egyébként innovatív termékeik hiányosságai miatt. A nem megfelelő, vagy nem jól alkalmazott irányelvek, pláne folyamatokba kódolva, nemcsak a termékek biztonságát befolyásolják, hanem azok piacra jutását is késleltetik, nagymértékben megnövelve a költségeket, a fejlesztési időt, valamint a termékek jövőbeni piaci elfogadottságát alááshatja.

Kulcsszavak: innováció, terméktervezés, termékbiztonság, tervezés, szabályozás.

\section{Bevezetés}

Napjainkban az egyik legfontosabb stratégiai kihívása az Európai Uniónak és hazánknak is az innováció felgyorsítása, hogy az egyes területeken jelentkező lemaradásunkat a világ többi gazdasági szereplőivel szemben le tudjuk dolgozni. Ennek egyik fontos része a KKV-k innovációs képességeinek a javítása, és bővítése. Sajnos a tapasztalatok azt mutatják, hogy a KKV-k nem rendelkeznek a megfelelő tudással az innováció és termékbiztonság területén, és ezáltal hátrányba kerülnek a többnyire nagy nemzetközi cégekkel szemben. Ennek következtében a cégek nagy része tudáshiány vagy a megfelelő kompetencia hiánya miatt nem megfelelően kezeli az innováció tervezését, különös tekintettel a biztonságos termékek fejlesztéséhez kapcsolódó folyamataikat, hatalmas károkat okozva ezzel saját maguknak, az egyébként innovatív termékeik hiányosságai miatt. A nem megfelelő vagy nem jól alkalmazott irányelvek, pláne folyamatokba kódolva, nem csak a termékek biztonságát befolyásolják, hanem azok piacra jutását is késleltetik, nagymértékben meg- 
növelve a költségeket, a fejlesztési időt, valamint a termékek jövőbeni piaci elfogadottságát is alááshatja. Napjainkra nagyon felgyorsultak az innovációs és termékfejlesztési folyamatok, és ennek köszönhetően a hagyományos üzleti folyamatok kiegészültek különböző gyorsító fázisokkal, mint az innováció előtti előkészítő fázis, valamint az ötleteket felismerő/megoldó, előtervezési fázisokkal, amelyeket Peter Koen elsők közt felismert és megfogalmazott, vizualizált (1. ábra).

\section{Az Innováció és termékfejlesztés ha- tékony felépítése, szakaszai és folya- matai}

Az innováció teljes folyamata napjainkra három fő csoportra tagozódott, melyek azonos fontossággal is bírnak egymáshoz képest. Nagyon fontos lett kiváltképp a nem folyamatos fejlesztési ciklussal rendelkező cégek életében az első szakasz az ún. innováció előtti fázis (IEF), mert ennek jó működése teszi igazán hatékonnyá az innovációs folyamat beindulását és sikerét, amit pl. sok start-up sikeresen is alkalmaz rugalmasságuknak köszönhetően. Természetesen hatékony második (termékfejlesztés) és harmadik (piacra juttatás) fázis nélkül sem lesz piacképes és sikeres egy termék. Ebben a tanulmányban az IEF- és a termékfejlesztési fázist szeretnénk áttekinteni a termékbiztonság kontextusában, de nézzük előbb, hogy hogyan épül fel ez a két fázis generalizált formában.

\subsection{FEI Front End of Innovation, avagy Inno- váció Előtti Fázis IEF}

Lássuk mi is az a FEI vagy másképp IEF. A már korábban is említett Peter Koen [1] szerint a legtöbben ezt a Stage Gate ${ }^{\mathrm{TM}}$ 3. kapuja előtti résznek tekintik, ami a PACE [2] szerint az 1-es kapunak

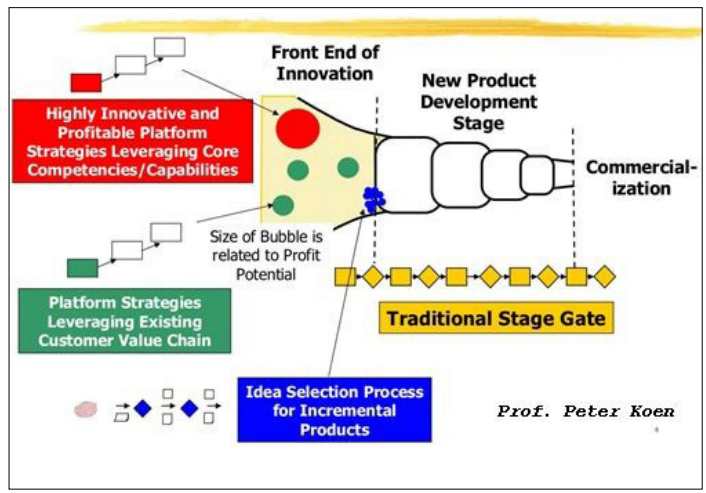

1. ábra. Az innováció teljes folyamata, Peter Koen felel meg, és amelyeket egy kapuval már korábbra sorolnánk mára a felgyorsult fejlesztési és újabb ötletvalidálási megoldások miatt. A IEF magában foglalja az összes olyan folyamatot, amelynek következtében új piacképes (vagy sem) ötleteket lehet generálni. Amely megvalósulhat különböző ötletgeneráló szoftverek, kreatív egyének, (dedikált) K+F csapatok, start-upok inkubációs/akcelerációs fázisának, speciális csoportok, különböző technikák, szakmai csoportok, felhasználói értékelések, úgynevezett konverterek, egyetemek és kutatóintézetek, klaszterek stb. segítségével. (2. ábra) Az IEF bármilyen kreatív lehetőséget magában foglalhat, ami arra ösztönzi az embert, hogy valami újat hozzon létre; a lényege, hogy megragadja a pillanatot, és tudja materializálni az ötletet. Manapság több olyan technika létezik, amely segíti a problémamegoldást, mint a hagyományos csoportos brainstorming vagy az újabb design sprintek készítése, a Design Thinking [3], Lean Start-Up [4], Biomimicry, Platform design, Business Innovation Design Framework stb. A fenti különböző technikák alkalmazása sokat segít az új innovatív ötletek felismerésében és a megoldások keresésében, megvalósításában.

A napjaink sikeres fejlesztései akkor tudnak igazán gyorsak és átütőek lenni, ha az első kapuig sikerül a problémát felismerni, a Perszónát sikeresen azonosítani, és a megoldást is körvonalazni olyan szintig, hogy az első kapu után a PACE szerinti termékfejlesztési folyamat valós koncepció alapján felállt projektcsapattal és kész megvalósítási tervvel indulhasson. Célszerű már ebben a fázisban is figyelembe venni a fejlesztendő termék termékbiztonsági megvalósíthatóságát és ennek kivitelezési lehetőségeit.

\subsection{Termékfejlesztés}

A sikeres cégek többsége a termékfejlesztés klasszikus PACE- [5] vagy a Stage Gate ${ }^{\mathrm{TM}}$ rendszerét illesztik a cég struktúrájához, és ennek segítségével végzik az inkrementális és az inno-

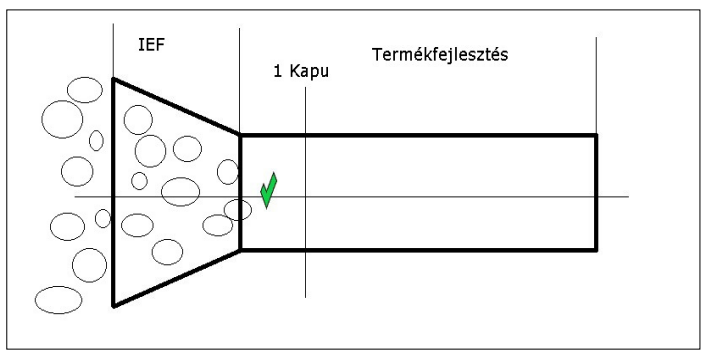

2. ábra. Az innováció első két folyamata, 
vatív termékfejlesztést. Röviden ismertetném a PACE-rendszer lényegét, hogy tisztábban lássuk annak a lehetséges kapcsolódási pontjait a termékbiztonsághoz a fejlesztés korai szakaszában.

A PACE jelentése (Product And Cycle-time Excellence) „Termék- és ciklusidő-kiválóság”, amely a teljes termékfejlesztést fázisokra bontott fejlesztési folyamatokra szakaszolja, minden szakaszt egy kapu bírálattal validálva lásd 3. ábra. A PACE-t használva a cégek nagyon sok felesleges időpazarlástól és költségtől tudják megkímélni magukat, felgyorsítva ezáltal a fejlesztés hatékonyságát és gazdaságosságát. A rendszer hatékony működésének részét kell, hogy képezze a felső vezetés hatékony és elkötelezett részvétele a kapubírálatokon a halaszthatatlan döntéshozás megvalósulása érdekében.

\section{Az innováció és a termékbiztonság korai összefonódása}

Akármilyen furcsa is, de az innovációs folyamat elején a 0 . kapunál egy döntést meg kell meghozni, azaz kategorizálni kell a terméket, hogy az pl. fogyasztási cikk, mint a gépjárművek, mobiltelefonok, stb. Ez nem mond ellent egyik agilis módszertannak sem, sőt azok köztudott magasabb integritásigényükre példa. Az integritáshoz köthető azon tény is, hogy egy terméknek az egyéb attribútumai mellett biztonságosnak kell lennie, erre vonatkozó információval bír a termék kategorizálása.

Maradva példánknál, a biztonság kapcsán kétirányú megközelítés képezi a mindennapi gyakorlatot, hisz a termékhasználók egészségének, biztonságának és gazdasági érdekeinek védelmén túl a termék környezetvédelme is elvárt. [6], [7]

A felhasználók szempontjából ez szükségszerüen nem azt jelenti, hogy a termék használata nem bír(hat) semmilyen kockázattal a felhasználókat illetően. Inkább azt, hogy a termékkel kapcsolatos kockázatok ismertek, és erről a felhasználókat tájékoztatták. Ezen elvárás viszont csak akkor teljesíthető maradéktalanul, ha folyamatosan dokumentált kockázatelemzés zajlik az innovációs tevékenység első lépéseitől. Nyilván ez annak az

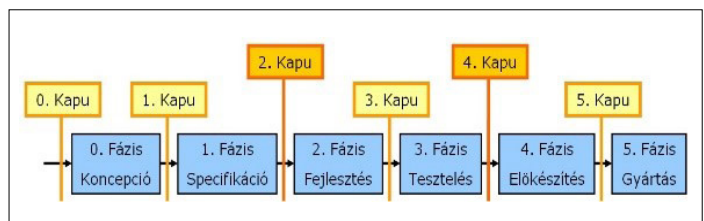

3. ábra. A PACE termékfejlesztési rendszer folyamata egyszerű kérdésnek a megválaszolását jelenti a legeslegelején, hogy a kívánt újítás/fejlődés (innováció) képez-e bármiféle kockázatot az egészségre, biztonságra, gazdasági érdekekre, illetve a környezetvédelemre tekintettel. Erre bináris válasz adható, igen, vagy nem. A „nem tudható” válasz is ,igen”, hisz az annyit tesz, hogy nem ismert egy veszély súlyossága vagy a kitettség mértéke, ami miatt a kockázatelemzés elkerülhetetlen. Azonban a kockázatelemzés szisztematikus kell, hogy legyen, így egyfajta úgynevezett előzetes, kockázatorientált, robusztus rendszertervezési koncepció metamodelljének megalkotása elkerülhetetlen. (4. ábra)

\subsection{Szisztematikus megközelítés}

Az agilis módszertanok, keretrendszerek mindegyike rendelkezik egy metamodellel, amely az abban megjelenő információk, lépések kapcsolatát, ok-okozati struktúráját írja le. Ez az információ az esetek többségében viszont nem publikus, oktatásokon keresztül lehet részben hozzáférni, a kapcsolódó üzleti modell végett.

Ez a fentebb említett tény, azonban óriási kihívást jelent már az első lépések megtételét követően, hisz kezelni kell egy információ-/tudáshiányos állapotot és annak már kezdetben is nagymértékű komplexitását.

Ehhez jön számtalan kezdeti feltételezés a termékkel kapcsolatban, ami majd, ha egyáltalán, a későbbiekben nyer megerősítést. Amelyek valamilyen módon, direkt vagy többszörös áttéten keresztül, de összefüggenek az előzőekkel.

Mindezek mellett a biztonságos termék nem más, mint jól végzett rendszermérnöki munka, ami a terméket felölelő kontextus minden aspektusát kezeli dinamikus módon, tehát nem csak a

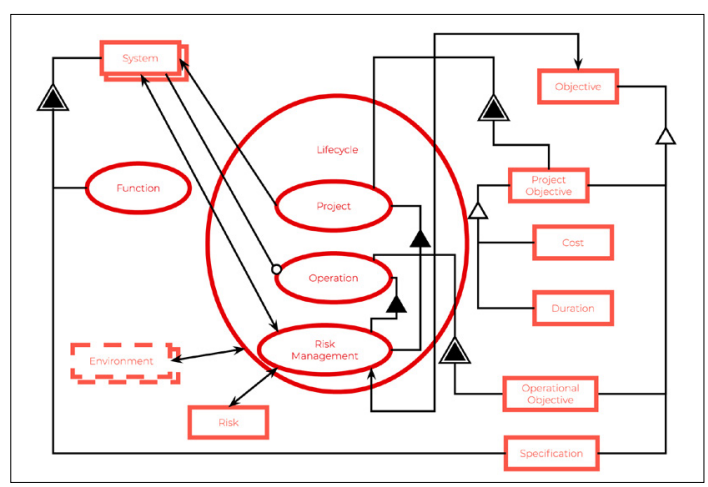

4. ábra. Elózetes kockázatorientált robosztus rendszer tervezési koncepció egy lehetséges metamodellje 
műszaki tartalomra koncentrál. Egyszerű következtetés, hogy a tudáshiány és komplexitás ellenére szükség van a kapcsolati viszonyok, egyszerűen, közérthető nyelven történő feltérképezésére attribútumokon átívelően, amely technikai és nem technikai szempontból is kellően informatív. Ilyen módszert ír le az ISO/PAS 19450:2015 szabvány. [8]

Ennek hiánya csak biztonságtechnikai lencsén keresztül szemlélve is erős kétséget ébreszt a minimális relatív biztonság elvárásait tekintve, illetve egy jól felépített, pl. PACE termékfejlesztési folyamatot feltételezve az új információk kontextusbeli beágyazottságának hiánya, ellentmondás-elemzés nélkül, a projekt megállítását eredményezi.

\section{A Termékbiztonság}

Ez a fajta komplex megközelítés (5., 6. ábra) nem túlzó, hanem minimálisan elvárható, ennek igazolásául tekintsük át az alábbi példát. Egy KKV elektromosjármű-fejlesztése kapcsán a jogi keretrendszerből fakadóan (7. ábra) egyebek mellett az alábbi követelményeket kell, hogy figyelembe vegye.

A piros keretes részek két dologról tájékoztatnak;

(I) „5. cikk”; megfordítja a gépjármű egészére vonatkozó típusmegfelelőség bizonyítási kényszerét, így bármely kétely az engedélyező hatóság részéről a típusjóváhagyás elmaradását eredményezheti [9].

(II) „8. cikk; A szerződésszerűség objektív követelményei

(1) A digitális tartalomnak, illetve a digitális szolgáltatásnak a szerződésszerűség szubjektív követelményei mellett az alábbi követelményeknek is meg kell felelnie:

(a) alkalmasnak kell lennie arra a célra, amelyre az azonos típusú digitális tartalom vagy szolgáltatás szokásosan használatos lenne, figyelembe véve adott esetben a hatályos uniós és tagállami jogszabályokat és múszaki szabványokat, illetve ilyen műszaki szabványok hiányában az alkalmazandó ágazatspecifikus magatartási kódexeket.” [10].

Ez magyarul annyit tesz, hogy a gyártónak az összes elérhető, a tudomány állása szerint innovatív megoldást, tudást alkalmaznia és dokumentálnia kell a termékfejlesztés során, hogy egyebek mellett a biztonságot szavatolja, és ezen erőfeszítéseit igazolni tudja, egy esetleges későbbi jogorvoslati eljárás során is.

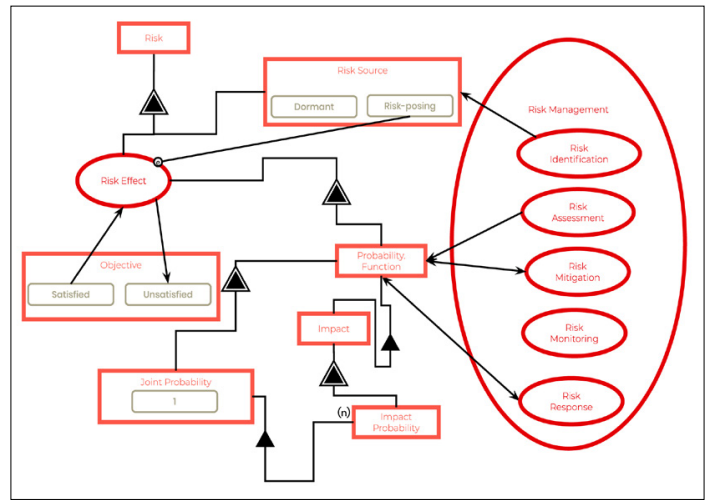

5. ábra. Kockázatkezelés egy lehetséges modellje

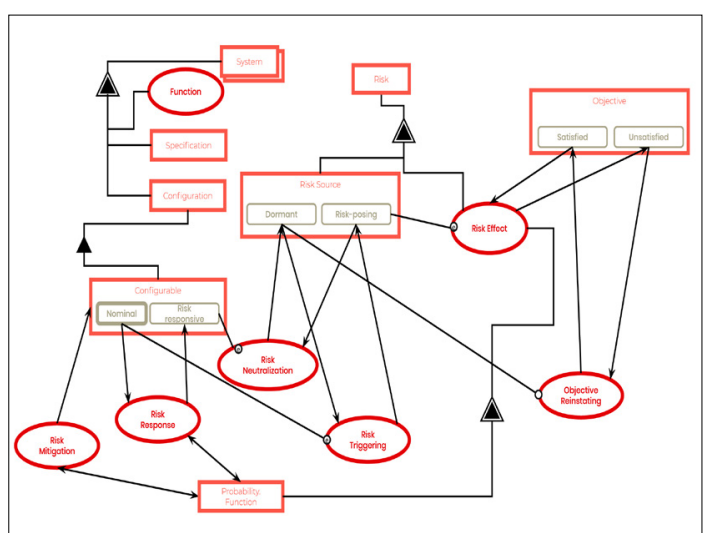

6. ábra. Kockázatkezelés egy lehetséges kifejtett modellje

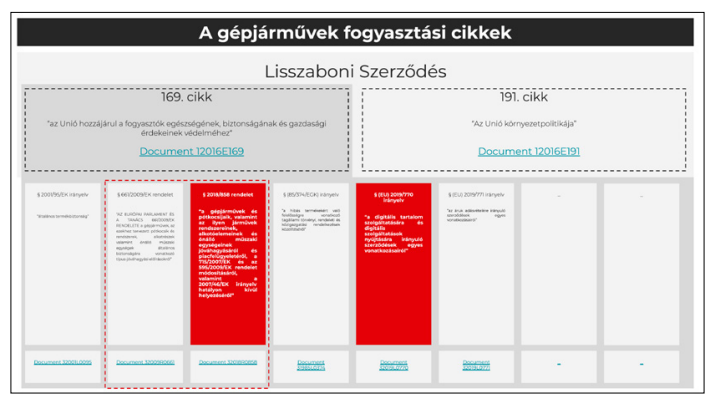

7. ábra. A jogi keretrendszerből fakadó követelmények

Ezen elvárás olyan komplexitással bír, hogy a legnagyobb autómárkák is nehezen birkóznak meg a feladattal, amennyiben ez nem része a kezdetektől a szisztematikus innovációs folyamataiknak, így könnyen belátható, hogy a KKV-k számára pedig csak az az egyetlen út, hogy a kezdetektől pl. a cikkünkben részlegesen bemutatott könnyüszerkezetes, de rendszerezett módon kezeljék az innovációs folyamataikat. 


\section{Következtetések}

Következtetésként levonható, hogy egy KKV csak akkor tud hatékony innovatív termékfejlesztést sikeresen működtetni, ha rendelkezik vagy hajlandó kiépíteni a következő stratégiai tudást a cégen belül:

- termékfejlesztés és termékbiztonság ismerete és cégen belüli szabályozása;

- a termék felhasználási környezetének alapos ismerete;

- vállalaton belüli közös nyelv kialakítása és tudásbázis felépítése;

- alkalmazottak innováció iránti elkötelezettsége és komplexitáskezelési képessége.

\section{Szakirodalmi hivatkozások}

[1] P. Koen P., A. Ajamian, G., Boyce, S., Clamen, A., Fisher, E., Fountoulakis, S., Johnson A., Puri. P., Seibert, R.: Fuzzy-Front End: Effective Methods, Tools and Techniques, PDMA Toolbook for New Product Development, P. Belliveau, A Griffen, S. Sorermeyer, John Wiley and Sons. 2002, 2-35.

[2] McGrath E. M., Anthony T. M., Saphiro R. A.: Product Development: Sucesss Through Product And Cycle-Time Excellence, Butterworth-Heinemann, Newton, 1992, 1-260.

[3] Luchs G. M., Swan K. S., Griffin A.: Design Thinking: new product development essentials from the $P D M A$, John Wiley \& Sons, Hoboken, New Jersey, 2016, 1-431.
[4] Eric Ries: The Lean Statup, Crown Publishing Group, USA, 2011, ISBN 0307887898

[5] McGrath E. M., (revised edition), Setting the PACE in product development: a guide to product and cycle-time excellence, Butterworth-Heinemann, Newton, 1996, 1-184.

[6] Consolidated version of the Treaty on the Functioning of the European Union, Part 3 - Union Policies And Internal Actions Title XV - Consumer Protection, Article 169

http://data.europa.eu/eli/treaty/tfeu_2016/ art_169/oj

[7] Consolidated version of the Treaty on the Functioning of the European Union PART THREE - UNION POLICIES AND INTERNAL ACTIONS TITLE XX - ENVIRONMENT Article 191

http://data.europa.eu/eli/treaty/tfeu_2016/ art_191/oj

[8] ISO/PAS 19450:2015 Automation systems and integration - Object-Process Methodology.

[9] Regulation (EU) 2018/858 of the European Parliament and of the Council of 30 May 2018 on the approval and market surveillance of motor vehicles and their trailers, and of systems, components and separate technical units intended for such vehicles, amending Regulations (EC) No 715/2007 and (EC) No 595/2009 and repealing Directive 2007/46/EC.

http://data.europa.eu/eli/reg/2018/858/oj

[10] Directive (EU) 2019/770 of the European Parliament and of the Council of 20 May 2019 on certain aspects concerning contracts for the supply of digital content and digital services. http://data.europa.eu/eli/dir/2019/770/oj 